\title{
Research Article: Determinants of total factor productivity growth of cotton in Telangana state
}

Article Chronicle:

Received :

12.07.2017;

Accepted :

25.07.2017

\section{KeY Words:}

Total factor productivity (TFP), Tornqvist indices, Parametric approach, Cotton productivity

Author for correspondence :

\section{DEEP NARAYAN}

MUKHERJEE

Department of Agricultural Economics, College of Agriculture, Professor Jayashankar Telangana State Agricultural University, HYDERABAD (TELANGANA) INDIA

See end of the article for authors' affiliations

\author{
DEEP NARAYAN MUKHERJEE, N. VASUDEV, R. VIJAYAKUMARI AND \\ K. SUHASINI
}

SUMMARY : Growth of total factor productivity indicates the long term performance of the sector. The growth of TFP indicates that part of the output growth of sector which remains unexplained by the growth of basic inputs of production. An attempt was made in the present paper to estimate the performance of TFP growth of cotton crop and its determinants in Telangana state. Cotton has occupied a significant part in the Telangana agriculture in the last three decades as evident from $7.20 \%$ annual growth of area under cultivation of cotton from 1979-80 to 2012-13. The production of the crop also increased at an annual rate of $12.80 \%$ during the same period. The significant increase in the growth of production of cotton was made possible due to area expansion and productivity gain with introduction of Bt. cotton coupled with better farm management practices. TFP indices of cotton in Telangana were calculated to reveal the long term performance of the sector. It was revealed that TFP of cotton in Telangana increased at 6\% annually during 2000-01 to 2012-13 mainly due to rapid growth of output index (12\% annually). Government expenditure in agricultural research, education and extension and average annual rainfall were identified to be the major determinants of TFP growth of cotton the Telangana.

How to cite this article : Mukherjee, Deep Narayan, Vasudev, N., Vijayakumari, R. and Suhasini, K. (2017). Determinants of total factor productivity growth of cotton in Telangana state. Agric. Update, 12(TECHSEAR-

2) : 514-519; DOI: 10.15740/HAS/AU/12.TECHSEAR(2)2017/514-519. 